\title{
Welsh Nationalism, Language and Students' Trust in the UK Police
}

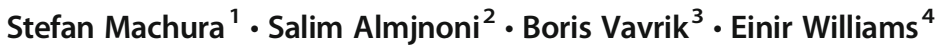

Published online: 15 September 2020

(C) The Author(s) 2020

\begin{abstract}
Where nationality, coupled to minority language, forms a key factor of identities, and there is a history of conflict, it may be difficult for the police to command trust. In northwest Wales, Welsh is the language of the majority. Against the background of historic experiences of exploitation, oppression, and perceived neglect by English authorities, many locals have a negative view of the UK police. But what characterises those who are most in opposition? A total of 283 students at Bangor University participated in a questionnaire study. Results show that students who prefer to communicate in Welsh rather than English are more likely to distrust the UK police. While there are deep rooted tensions based on national identity, the police may gain trust from different sources compensating the cultural divide. They include mass media reports and experiences with the police. Overall however, the results support the group position theory applied to relations between people identifying with different nations.
\end{abstract}

Keywords Trust in police $\cdot$ Welsh nationalism · Minorities and police $\cdot$ Group position theory

\section{Introduction}

Public trust is a crucial factor for state institutions (Easton 1965). Distrust may affect a range of policies and individual decisions (Easton 1965). In the widest sense, trust in institutions is the believe that they can be relied on to take beneficial actions. Trust in the state institutions suffers if they are perceived as partial towards certain segments of society. Where different

Stefan Machura

s.machura@bangor.ac.uk

1 School of History, Philosophy and Social Sciences, Bangor University, Bangor, Gwynedd LL57 2DG, UK

2 Makkah, Saudi Arabia

3 Belfast, UK

4 Gwynedd, UK 
nationality groups compete for influence, an area of conflict opens. As providing security and adequate responses to crime is commonly seen as a main task for states, it is likely that tensions extend to this area. The police are a key agency of the state, and citizens expect it to serve their needs. On the other hand, the police heavily rely on the public's cooperation. Deepening internal divisions in society and a broader trend of 'declining deference' have the potential to weaken trust in the police (for the UK since the 1960s: Reiner 1992, pp. 772-773; Reiner and O'Connor 2015, p. 48). Authorities and experts have been increasingly questioned (Hesse 1998), and there is less of a consent to respect and value the work of police. A range of developments has contributed to this situation, including far-reaching political and economic changes (Reiner 1992; Bowling et al. 2019, xv). Nevertheless, without chancing some trust in authorities (such as the police or the courts), life becomes very difficult for the individual and others (Luhmann 1975; Luban 1988, p. 7, Sztompka 1998). ${ }^{1}$ Apart from causes of distrust in operation throughout, such as a mismatch between on the one hand public expectations and on the other police resources and officer behaviour, or even their portrayal in the media, some causes are contingent on local constellations.

Where societies are divided by different national identities, trust is diminished when the police are perceived as favouring one part of the population or symbolise a state that is rejected (Weitzer 1985; Sahin and Akboga 2018). Minorities and majorities may demand that the police represent them. In addition, experiences of discrimination minorities have in general interaction with the majority population may also diminish their trust in the police (Van Craen 2012, pp. 1041-1044). The degree to which citizens trust the police can be influenced by the perception that police are on their side of a political or cultural divide. In the UK, examples include England (Loader and Mulcahy 2006), Northern Ireland (Ellison et al. 2013; Topping and Byrne 2016; Bradford et al. 2018) and north-west Wales (Machura et al. 2019). The present article turns to a sample of university students in north-west Wales some of whom may be especially determined in their nationalism, in order to clear up the causes of distrust in UK state authorities. In Wales, nationalism takes many forms and we tested several aspects that might be at the heart of their Welsh nationalism. A large part of the local population defines being Welsh by speaking Welsh and expect others to use the language too. Though, the Celtic language differs completely from English, and mastering it needs a long time and persistent practice. This article focuses especially on north-west Wales, where within living memory there were calls to create areas without any non-Welsh influences (Day 2002), and still the demand is heard to reserve all jobs exclusively for Welsh-speakers. We are covering a peculiar area of Wales, a nation which as a whole is much different, feels more 'English' at the Eastern boarders and is more cosmopolitan in Cardiff, the Capital of Wales, and where the language issue does not form a primary political concern in the South (Mann and Fenton 2017). Apart from exploring the language dimension of nationalism, other factors for trust in police will be considered. In this way, the study provides a rigid test of the influence of language-based nationalism on trust in UK institutions, here: the police. Although police in the UK is organised in four different national organisations: Wales, England, Scotland and Northern Ireland, for a Welsh nationalist there is in all likelihood a category of police outside of the Welsh political and cultural sphere, an institution that is part of the resented UK state. A police

\footnotetext{
${ }^{1}$ The present text addresses issues of trust in relation to institutions. For the analysis of trust in interpersonal relations, Barbalet (2009) has suggested a different concept. Levels of interpersonal trust and institutional trust can, of course, interact (Sztompka 1998, also Hardin 1992).
} 
that cannot be expected to share the values of the proverbial 'fro cymraig' - the beleaguered Welsh community, something 'theirs', not 'us'.

Unlike Northern Ireland and Scotland with their politics, Wales is a largely unknown entity in the UK and internationally. Therefore, this article will explain the intricate issues of national identity presenting themselves in Wales, and the relations between police and the public here. Our special focus will be on students in north Wales. While the area is the politically most estranged from England and the UK, students often express political dissent more clearly than other parts of a society.

Previous research in the UK has addressed attitudes to the police of e.g. the Muslim minority (Huq et al. 2011), BME ('black and minority ethnic') Londoners (Bradford 2014), or of more recent Polish immigrants (Griffith 2017). These, however, have mainly come to the UK after the end of the British Empire or after the Iron Curtain in Europe came down. Their situation will be different from a group that claims indigenous status, having settled on the land since times immemorial. In studying nationality or ethnicity, here: minority languages and trust in police, researchers are not limited to the general population. One could also be interested in special segments of society, as they often confront theories with a real test of the reach of their explanatory power. The present study is concerned with students' trust in the key state institution of the police and how students of Welsh background potentially differ from their colleagues.

\section{Welsh Nationalism, Language and Politics}

What differentiates Wales and the Welsh from other nations of the UK according to Graham Day (2002, p. 255), writing at the turn of the millennium, is 'owed more to cultural factors, such as the language and religion, but these have been, and are, internally divisive'. Today, with growing secularisation the religious dimension is much less relevant, but the language issue remains. For 33\% of respondents in an opinion survey in Wales, speaking Welsh 'makes a person Welsh' (Smith 2019).

People in Wales self-identify as either 'English', 'Welsh' or the more inclusive 'British' or a combination of these (Mann and Fenton 2017, pp. 192-196). A prominent discourse in Wales is on Welsh identity, often defined by speaking Welsh, and concerned with threats to predominantly Welsh-speaking 'heartlands' (Day 2015). One of the main aspects fuelling public sentiment is the influx of new residents (mainly from England) into those, competing on the labour and housing markets, while younger local people resort to leaving (Day et al. 2006, p. 579; Day et al. 2010, pp. 1406-1407, 1410-1411). As Day et al. (2010, p. 1412) put it:

There is ample evidence for the existence of a degree of latent antagonism between representatives of the English and Welsh in north Wales, which erupt from time to time into overt, albeit small-scale, conflict.

Another dimension is still very much alive in at least north-west Wales: the identity-politics between fluent and first language Welsh-speakers and those defining their nationality by other symbols of 'Welshness' (Osmond 2009, pp. 4-5; Mann 2004; Mann and Plows 2016). What constitutes Welsh identity and if it must be different from 'English' or 'British' identities is variable, up to individual attitude and in some quarters highly contested (Day 2002, pp. 241244; Mann and Fenton 2017, pp. 192-196). A minority of Welsh nationalists is especially zealous about their language and culture (Day 2002, pp. 241-244; Day et al. 2006, pp. 579580, 589). Some first-language speakers, mixing English and Welsh in everyday life and using 
a local vernacular of the Celtic language, feel looked down upon by highly educated speakers (Day 2002, pp. 251-252, 216). The language thus is a marker of ethnic and class distinctions in more than one way. The more tension there is around speaking the language and differentiation around its correct use, the dearer its preservation becomes to the nationalist core. For some, issues of language influence careers, voting behaviour, social networks to master everyday life, even friendships and the choice of shops to go to and neighbourhoods to live in.

The Welsh language and culture is supported by political measures. Most prominent is the requirement to speak Welsh in public offices. Many private and third sector organisations also demand speaking the local language from their staff. Another policy advocated by some campaigners and adopted by some local councils aims to support Welsh language neighbourhoods by controlling the housing market to the advantage of Welsh-speakers (Day et al. 2006, pp. 579-580). The North Wales Police has adopted a policy of bilingualism, affecting the marking of patrol cars, uniforms, signs, leaflets and websites. Non-Welsh speaking locals, however, often feel disadvantaged by measures to support the use of the Welsh language. Yet, successes of Welsh campaigners have not pushed aside the concerns of those who strongly identify with the Welsh language and culture, more so of locals who define themselves in opposition to the 'British/English establishment'.

Indeed, some perceive Wales as a colony of England and the attitude of 'the' English in north Wales as 'colonialism' (Day et al. 2010, pp. 1408, 1413). In historic memory, times are not forgotten in which measures had been taken to suppress the use of the Welsh language. In Welsh politics, communitarian approaches are more prominent than liberal and free-market ideas. According to Harris (2014), there is 'a deeply ingrained sense that Welsh people are a particular kind of people of moral worth'. Welsh nationalism locates itself traditionally left of the centre (Mann and Fenton 2017, p. 8).

In addition, the government in London and the UK as a state are widely perceived as neglecting Wales economically and culturally. 'Performance legitimacy is undermined when a state is unable/unwilling to attend to structural inequality on a regional basis' (Hamilton 2004, p. 658). In a nationalistically loaded atmosphere, even law-breaking gets of whiff of resistance against a distant and uncaring authority, for example poaching and not filling in tax forms (Emmet 1964; Day 2002, pp. 231-232). Resentment against English authorities may also still linger as it took widespread civil disobedience tactics to raise the Welsh language issue politically in the 1970s (Day 2002, pp. 218-219). From 1979 to the mid-1990s, violent actions against English in-migrants on the Llyn Peninsula, including arson attacks against second homes, raised tensions again (Carter 2004). Today, the ongoing closures of local industries are credited to a disinterested London government and Brexit - the 2016 UK referendum decision to leave the European Union-fuels concern that once again Welsh interests are sacrificed for centralised policy approaches.

Apart from the largely deindustrialised south Wales Valleys, the key stronghold of Welsh language is north-west Wales. Of those who answered the question in the 2018 population survey, $77 \%$ in the county of Gwynedd and $68 \%$ on the Isle of Anglesey said they were Welsh-speakers (Stats Wales 2019). Nevertheless, the language is in a long-term decline (Day et al. 2010, pp. 1406-1407). In addition, the region has suffered from prolonged economic crises causing fierce competition between locals and newcomers over the remaining income opportunities.

The party politics of north Wales are also special. While in the 2016 Welsh Assembly elections, the Plaid Cymru party ('Voice of Wales'), which supports independence, had a 
$20.5 \%$ vote share in Wales overall (BBC n.d.), on Anglesey and in the Arfon constituency of Gwynedd it had more than half of the voters (Jones and Holzinger 2016, p. 20). Welsh nationalists tend to see the European Union as a counterweight to the powers centralised in London. About 69\% of fluent Welsh-speakers favoured staying in the EU (Mann and Fenton 2017, p. 200). In the European Parliament elections of May 2019, the three counties Gwynedd, Anglesey and neighbouring Ceredigion saw pro-European Plaid Cymru in the lead, whereas in the rest of Wales the Brexit Party was strongest (BBC news 2019). Data sampling for the study presented here preceded the Brexit situation; however, the different stance in the north-west Wales region highlights the deeply rooted alienation of many locals from UK politics.

Cuts in police budgets have led to very low police presence in rural north-west Wales. But, to develop trust in the police, their visibility is required (Dalgleish and Myhill 2004, p. 241; Quinton and Tuffin 2007). The local police believe that levels of trust are lower in the more Welsh-speaking rural areas. Some types of crime have much higher occurrence in rural areas. A local study on farm crime showed that it is typically not even reported to the police (Jones and Holmes 2013). Or, in rural areas, victims of hate crime found it difficult to mobilise the police in support (Williams and Tregidga 2014, p. 950).

As Max Weber already taught, when a social order is not seen in a favourable light, as 'exemplary' and 'binding', it does not command high levels of support (Weber 1968, p. 31). Group position theory, formulated initially in the USA to explain racism (Blumer 1958; Weitzer and Tuch 2005), can be applied to the relation of national minorities with the police (Bradford and Jackson 2018; Sahin and Akboga 2018). The group finding itself disadvantaged, or dominated, perceives authorities more negatively as to them it represents the dominant group and the order it established. In the Welsh context, nationalism takes different guises and people adopt different stances in relation to 'Welshness'. Attitudes are in flux. But a minority defines itself in opposition to the UK authorities. Still, other factors, unrelated to national identity, may influence trust in the police.

\section{Other Factors Explaining Trust in the Police in a Welsh Context}

Previous research in north-west Wales has identified some factors relevant for students' trust in the police (Heenan et al. 2008; Dalton et al. 2009; Machura et al. 2013, 2019). Older students showed less overall trust (Machura et al. 2014); they might have had more negative personal experiences, news coverage or other information. One special aspect is the influence of university education on trust in the police. In a previous panel study focused on law students, police trust was related to aspects of studying law and to discussions with fellow students (Machura et al. 2014). Another study has shown that members of the general local population in Bangor and neighbouring areas trust the local North Wales Police-which has adopted a strictly bilingual policy_more if they prefer to communicate in Welsh (Machura et al. 2019). The present article instead focuses on the question if there is a link between distrust of UK police and Welsh identity defined by language preference among a student population that is likely to have more radical Welsh nationalists.

An extensive body of research exists on trust in the police. Tyler and Jackson (2013, p. 13) summarised that trust is

the belief that the police can be relied upon to act competently (be effective), to wield their authority in fair ways (be procedurally just), and to provide equal justice and protection across society (be distributively fair). 
The following study uses police effectiveness, procedural fairness and distributive justice as indicators of trust. As much of the literature on institutional trust, this concept emphasises perceived trustworthiness of the institution: the experienced or just ascribed qualities of those who are trusted or distrusted, or trusted up to a point only.

Trust is subject to fluctuations and different perceptions within a variety of social milieus. Comparative studies throughout Europe have shown low trust in state institutions, where oppression or upheaval was present. Citizens may learn to distrust state authority and perpetuate this culturally (Sztompka 1998). Many Eastern European countries, like Bulgaria and Russia, have a climate of distrust while police in e.g. Scandinavian countries is highly trusted (Jackson et al. 2011, pp. 5-8; Machura 2011, pp. 244-245). One part of the UK, in which there is a widespread unease with central government based on historical grievances and current issues, is Wales. It is possible that some Welsh citizens still perceive the police as part of an English-dominated state suspected of restricting the use of the Welsh language and having no respect for Welsh culture and identity.

In general terms, 'trust' in institutions and their representatives is linked to public opinion on their effectiveness, distributive justice and procedural justice (Sunshine and Tyler 2003; Tyler and Huo 2002; Dirikx et al. 2013; Tyler and Jackson 2013; Dirikx and Van den Bulck 2014, only effectiveness and procedural justice in: Czapska et al. 2014, pp. 462-463). One of the crucial factors increasing trust in the police proved to be fair treatment. It symbolises group identity and values, and those who are treated unfairly, are made to feel unaccepted and unprotected (Tyler and Lind 1992; Tyler 2006).

While people in general value to be treated fairly by authorities, in one study by Tom Tyler, Californians who rejected an overarching national American identity and rather cultivated a separate, for example Hispanic, group identity showed a different pattern. For them, the outcome received proved more important than the procedural fairness of legal authorities (Tyler 2000). In another study, Australians who professed an eagerness to retain a 'separate cultural identity' based on their 'ethnic/racial' affiliation had more of a preference to judge police by its performance rather than by its procedural fairness (Murphy et al. 2015, pp. 730732 , testing antecedents of willingness to cooperate). However, people who identify with another group may also be especially vigilant about the fairness of authorities, as they may look out for signs of being disadvantaged. In one study, young male minority ethnic Londoners were split into those feeling as citizens of other countries and those feeling as UK citizens. The former showed an even higher relation between perceived procedural fairness and their social identity held (Bradford 2014, pp. 33-34). Group position theory (Weitzer and Tuch 2005) suggests that groups dominated by others will be especially prone to perceive discrimination. This, however, is contingent on circumstances and social perception. In study, a wide-spread identification with the Australian culture and state correlated with more positive attitudes towards the police (Oliveira and Murphy 2015, pp. 270-273).

Overall, there is growing evidence that individuals judge institutions by the fair behaviour of their agents (Tyler and Lind 1992; Dalton et al. 2009 for north Wales; Tyler et al. 2015). Citizens expect to be treated fairly, by decision makers who try hard to arrive at a solution, appear impartial, and respect people's rights (Leventhal 1980; Machura 2001; Tyler 2006; Myhill and Beak 2008, pp. 125, 127; Jackson and Sunshine 2007; Lind 2019).

Another contributing factor to trust in institutions is the media. The news content can have an influence on trust (Dirikx et al. 2013). Most fictional TV programmes present police and law professionals in a positive light which influences the public's opinion on law enforcement agencies (Asimow et al. 2005; Machura 2006; Machura and Kammertöns 2009). More 
recently, so-called 'reality police shows' have become highly popular among viewers. For instance, 'Traffic Cops' was a show that follows officers during the pursuit of their routine duties. Although heavily edited, the shows purportedly depict the 'reality' of policing. The effect on trust in the police is yet to be further determined (Dirikx et al. 2013; Machura et al. 2014). The media are only one of several factors that can be classified as 'indirect experiences' with institutions. Other such influences are family members working for - in this case- the police, or discussions with family and friends (Dalton et al. 2009; Machura et al. 2013). People must rely on indirect experience in the absence of direct exposure (Dirikx and Van den Bulck 2014, p. 359). Yet, it is likely that individuals have encountered the police and memorise fair or unfair treatment, competent or incompetent behaviour. Victims of crime in the UK reported a rather positive experience (Bradford et al. 2013, p. 88). As a rule, self-initiated contact with the police leaves a more positive impression than police-initiated contact. The former category would include talking and reporting to police, the latter may refer to adverse experiences such as being stopped or fined by police.

Age and gender of individuals may lead to different accumulated experiences and thus may have a relation with trust in the police. Though, age is unlikely to have an effect in a student sample as most of the respondents are of a similar age. A gender effect may also not be in evidence as students share years of higher education as common life experience. However, in a survey of trust in Police Community Support Officers - uniformed officers with only limited training and restricted legal powers - male students at Bangor University in north Wales expressed lower trust than female students (Heenan et al. 2008, 144), In other studies with samples including not just students in north Wales, no significant contribution was found for gender to trust in the local North Wales Police (Dalton et al. 2009, 104) and for gender and age (Machura et al. 2019, p. 70). Domestic and international students differ by the time they have spent in the UK. In a panel study with law students in north-west Wales, the longer students were in the country, the less they trusted the police (Machura et al. 2014, p. 296). This result may indicate that UK students picked up more negative impressions of the police, whereas many foreign students, arriving just for their studies, have a particularly positive attitude towards UK police. Another way to conceptualise this is to ask about the country students are from. Chinese students form a large section of learners at UK universities. Chinese culture according to authors including Geert Hofstede (1993, 1997, p. 32) is characterised by stricter allegiance to authorities. Students from this country may extend a trusting attitude to the police of their guest country.

\section{Hypotheses}

Our main hypothesis is that students who have a strong Welsh identity will have less trust in the UK police. More specifically, it is assumed that Welsh-speakers are most prone to such distrust. In addition, based on previous research, we assume that students' trust may be affected positively by the consumption of law-related media, as well as by direct experiences with the police and by their studies, while we assume that age and gender have no significant influence. Non-UK students may have higher trust in the UK police than those who have spent more years in the country.

From introducing the methods used for this project and the demographic characteristics of our sample, this article moves on to measures of Welsh nationalism, the level of trust in police and then turns to further sources of trust in the police. The article 
concludes with a discussion of the results, theoretical and practical implications, which are relevant beyond Wales.

\section{Data and Methods}

Bangor University, placed in the Welsh heartland of Gwynedd county, made it part of its mission to preserve the Welsh language (Roberts 2009, p. 4). Together with a sizeable portion of English, European and international students, it still attracts most of the students from northwest Wales. Among its students is a highly self-confident and politically engaged segment of Welsh-speakers. A minority of students at Bangor University even attends Welsh medium modules and degrees. The present survey on police trust among Welsh students will therefore be conducted at Bangor University.

A purposeful sampling design was chosen: final year students from a variety of subjects, including classes with a higher proportion of Welsh-speakers, as our special focus was on students with strong Welsh identity. In the first quarter of 2014, third year students at Bangor University from the following subjects were visited in class. The resulting sample has 102 business students (36\% of the sample), 66 law students (23.3\%), 58 social science English and 9 social science Welsh medium students ( $20.5 \%$ and $3.2 \%$ of the sample), as well as 35 students from education English and 4 from education Welsh medium classes (12.4\% and 1.4\% of the sample). Fourth year German language students $(9,3.2 \%$ of the sample) were also included, studying 4 years (they spent 1 year abroad). The relative sizes of the different classes roughly reflect the numbers of students in those degrees. Especially Welsh medium classes are small, as by far most Welsh-speakers prefer English medium tuition.

Respondents were told of the voluntary nature of their participation and answered anonymously. The study complies with the Ethics Guidelines of the British Society of Criminology and of Bangor University. It was approved by the Ethics Committee of the College of Business, Law, Education and Social Sciences.

The questionnaire headed 'Survey of opinion about UK police' started with inquiring about the age (noted in years) and gender (coded as ' 0 ' for male and ' 1 ' for female) of the respondent and how long they lived in the UK. The respondents' country of origin was covered, especially as mentioning 'Wales' rather than 'UK' or 'Great Britain', is a marker for a sense of national pride. Belonging to a specific country was dummy coded: ' 1 ' for belonging and ' 0 ' for not belonging to a country. Respondents also stated in which year of studies they were in.

The next set of questions was introduced 'What do you think of the UK police' and contained items (see Table 1 and accompanying discussion below) used in a previous study with law students (Machura et al. 2014, p. 157; Machura et al. 2014, p. 293; similar items were devised by others, e.g. Tyler 2006). Respondents answered on a fivepoint scale running from 'very' (coded as ' 1 ') to 'not at all' (coded '5'), with a 'do not know' option. A range of perceived influences was offered (see Table 3), preceded by 'People often form their opinions based on different sources of information', accompanied by a five-point scale from 'very' (coded ' 1 ') to 'not at all' (coded ' 5 '). The majority of the items had already been used in the earlier law student study (Machura et al. 2013, p. 159; Machura et al. 2014, p. 294, following the methodology in Asimow et al. 2005, p. 417). It was followed by items, again from the law student study (anonymised), on the 
Table 1 Trust in police and procedural fairness by officers, percentages

\begin{tabular}{llllrll}
\hline & $1=$ Very & 2 & 3 & 4 & $5=$ Not at all & Correlation with 1 \\
\hline 1. Overall trust & 20.5 & 41.0 & 24.0 & 9.2 & 1.4 & - \\
2. How well they work & 13.8 & 33.9 & 29.7 & 9.9 & 0.7 & $.71^{*}$ \\
3. How just their actions are & 11.0 & 33.6 & 32.9 & 6.7 & 1.4 & $.68^{*}$ \\
4. Trust in procedures & 15.9 & 32.5 & 28.3 & 13.8 & 2.5 & $.73^{*}$ \\
5. Effectiveness & 11.0 & 33.2 & 34.3 & 13.1 & 1.8 & $.56^{*}$ \\
6. Officers treat citizens fairly & 13.1 & 28.3 & 32.2 & 12.0 & 4.6 & $.64^{*}$ \\
7. Officers try to serve justice & 12.7 & 35.0 & 32.9 & 6.0 & 1.1 & $.59^{*}$ \\
\hline
\end{tabular}

Percentages: differences to 100 are missing answers and 'do not know'. Correlations are Spearman Rho, $239 \leq$ $n \leq 261, * p<.01$

influence of the degree course, lecturers, assigned readings and discussion with fellow students, preceded by the prompt 'Regardless of your degree course, please answer the following questions to the best of your ability'. Respondents ticked either 'positively' (coded '1'), 'neither' ('2'), 'negatively' ('3') or 'don't know'. In order to obtain an updated list of TV series related to police, crime and law, students in other classes have been asked for the series they watched. The list included twelve shows, and the respondents of this study were asked how often they were watched. The most popular series - 'very' often watched by $6.4 \%$ (coded ' 1 '), 'often' by $16.3 \%$ (coded ' 2 '), 'sometimes' by $27.6 \%$ (coded ' 3 '), 'rarely' by $10.2 \%$ (coded ' 4 ') and 'never' by $38.5 \%$ (coded ' 5 ')_-proved 'Traffic Cops'. It will be used in the multivariate analysis.

To cover relevant aspects of Welsh language preference and Welsh identity, a new series of questions was developed. For the most basic question, respondents were asked if they speak Welsh as 'first language' (coded as ' 1 '), 'fluent' (coded '2'), 'I can get by' (coded '3'), 'a few words' (coded '4') or 'not at all' (coded '5'). The core Welsh-speaking community may have a strong preference to use their language in as many situations as possible. The prompt 'Do you prefer Welsh when speaking' started a list containing 'with family', 'with friends', 'at work', 'with police', 'in shops', 'at university', 'with your GP', and 'with public administration staff', Each time, rating was possible on a five-point-scale ranging from 'very' (coded ' 1 ') to 'not at all' (coded '5'). A related set of items with the same response options and coding asked if there were enough Welsh spoken in the various places (see Table 2 below). Finally, respondents were given a list of financial and other policies that would benefit Welsh-speakers over others (Table 2). Again, the same 5-point-scale was available.

Some consider Welsh language neighbourhoods as essential for the survival of the language. Thus, an item inquired 'Is your neighbourhood? [answers:] primarily Welsh-speaking [coded ' 1 '] /a mixture of both [' 2 '] /primarily English-speaking [' 3 ']'. The questionnaire closed with an opportunity to leave "any other comment" in text form.

The 283 survey participants were mostly in their third year of study at Bangor University $(91.5 \%)$, very few in their second $(2.5 \%)$ and fourth $(4.9 \%){ }^{2}$ They were aged between 18 and 54 years. Median age was 21 years (arithmetic mean 22.9). Most of the students were female $(70.7 \%)$. Students had lived in the UK for 15.8 years on average (median $=20$ ). This means that many have spent at least some time of their life outside of the UK. $29.3 \%$ of the respondents have been in the UK for 4 years or less and it is likely that they have arrived only for their studies. The different respondent groups allow comparisons.

\footnotetext{
${ }^{2}$ Three students did not indicate their year of studies, six their age, three how long they lived in the UK and four students their gender.
} 
Table 2 Welsh language preference and Welsh language policy

\begin{tabular}{|c|c|c|c|c|c|}
\hline & $1=$ Very & 2 & 3 & 4 & $5=$ Not at all \\
\hline \multicolumn{6}{|l|}{ Prefers Welsh when speaking... } \\
\hline With family & 14.5 & 2.5 & 4.2 & 2.5 & 65.7 \\
\hline With friends & 12.4 & 3.5 & 7.1 & 4.9 & 60.8 \\
\hline At work & 11.0 & 4.2 & 6.7 & 3.2 & 63.6 \\
\hline With police & 10.6 & 3.2 & 5.7 & 1.8 & 67.8 \\
\hline In shops & 10.6 & 3.2 & 7.1 & 4.2 & 64.0 \\
\hline At university & 10.2 & 3.2 & 7.1 & 4.2 & 64.3 \\
\hline With your GP & 10.2 & 1.4 & 5.3 & 0.7 & 71.4 \\
\hline With public administration staff & 9.9 & 3.5 & 6.4 & 3.5 & 65.7 \\
\hline \multicolumn{6}{|l|}{ Enough Welsh spoken } \\
\hline In schools & 20.8 & 18.7 & 25.1 & 7.8 & 18.0 \\
\hline At university & 19.1 & 18.0 & 26.9 & 9.9 & 16.6 \\
\hline In administration & 17.0 & 16.6 & 27.6 & 8.5 & 20.5 \\
\hline At the GP surgery & 14.5 & 16.3 & 27.6 & 7.4 & 24.0 \\
\hline In shops & 2.7 & 14.1 & 31.4 & 10.6 & 21.2 \\
\hline By the police & 11.7 & 14.8 & 32.2 & 10.6 & 20.8 \\
\hline \multicolumn{6}{|l|}{ Support of policies } \\
\hline \multicolumn{6}{|l|}{ Extra funding for } \\
\hline Welsh classes & 24.4 & 19.4 & 22.6 & 6.4 & 22.3 \\
\hline Welsh cultural events & 18.7 & 21.9 & 24.7 & 8.5 & 20.8 \\
\hline \multicolumn{6}{|l|}{ Welsh required for jobs } \\
\hline at schools & 16.6 & 10.6 & 20.5 & 10.2 & 36.7 \\
\hline at the NHS & 15.5 & 10.6 & 18.7 & 12.7 & 36.7 \\
\hline at the police & 14.1 & 12.0 & 21.6 & 9.5 & 37.5 \\
\hline in administrations & 12.4 & 11.0 & 22.6 & 8.8 & 39.9 \\
\hline in shops & 12.0 & 10.2 & 21.6 & 10.2 & 40.6 \\
\hline
\end{tabular}

Percentages: differences to 100 are missing answers

\section{Results}

\section{Trust in the UK Police}

Respondents rated questions about trust in 'the UK police' (Table 1). Answers tended to fall into the middle categories. Asked 'Overall, do you trust the police?'; a majority provided positive responses $(61.5 \%)$. When it comes to police effectiveness, $49.2 \%$ indicated doubts. When asked whether officers try to serve justice, $40 \%$ did not provide a positive answer. The evaluation of the remaining items showed a similar pattern. To measure trust, an index variable was formed of the seven variables in Table 1 (Cronbach's alpha $=.927, n=212){ }^{3}$ This index will be used as dependent variable.

\section{Exploring Different Dimensions of Welsh Nationalism}

A range of aspects could be key when it comes to the definition of what being 'Welsh' means and what defines those Welsh student nationalists who are especially critical about UK authorities such as the police. The range includes identifying as 'Welsh' rather than 'English'

\footnotetext{
3 There were also two items on officer abuse of power and officer prejudice. Their inclusion would have resulted in a lower $n(=194)$ and alpha (= .889). A factor analysis (principal component, direct oblimin rotation) supports the decision to not include those two items.
} 
and 'British', living in a Welsh-speaking community, worrying about Welsh being spoken widely enough, supporting measures to strengthen the Welsh language and having a clear preference for the Welsh language.

When students have been asked about their country of origin, they most frequently indicated 'Wales' (30\%), followed closely by China (24\%), then 'UK' (15.9\%) and 'England' $(15.5 \%)$. The rest came from 23 different countries in Europe and beyond. ${ }^{4}$ Of the respondents, $13.8 \%$ identified Welsh as their first language and a further $4.6 \%$ said they were fluent in Welsh. Another $11 \%$ stated that they could 'get by' with the Welsh language and $18.1 \%$ spoke a few words. The remaining 52.5\% did not speak Welsh at all. When asked, $13.1 \%$ stated they lived in a primarily Welsh-speaking and $46.3 \%$ in a primarily English-speaking neighbourhood. A mixed neighbourhood was indicated by $29 \%$, while $11.7 \%$ chose not to answer the question.

A set of items asked whether enough Welsh were spoken in a variety of situations. The responses (Table 2) were roughly split into three equal groups that agreed, disagreed or were undecided if there is enough Welsh conversation in schools, at university, in administrations, at GP surgeries, in shops and by the police. The six variables were combined to an index for enough Welsh spoken (Cronbach's alpha $=.949$ ).

The respondents have been asked about their preference to speak Welsh in certain situations: with family or friends, at work, with police, in shops, at university, with their GP and public administration staff. A clear majority of the students had no such preference, as shown in Table 2. Only $17 \%$ at most, indicated their preference for Welsh language in any of these situations. An index variable was formed out of the eight individual items to measure the overall preference for using the Welsh language (Cronbach's alpha $=.984) .^{5}$ It is negatively correlated to trust in the UK police on a bivariate level (Pearson's $r=-.15, p<.05, n=188$ ). The higher the preference to speak Welsh, the lower the level of trust.

In relation to a range of policies supporting the Welsh language (Table 2), most tended to be rejected, except for extra funding for Welsh classes and Welsh cultural events. Again, an index variable was computed (Cronbach's alpha $=.942$ ). The respondents' inclination towards language measures can be statistically explained to a large extent by overall preference to speak Welsh. ${ }^{6}$

\section{Sources of Trust in the UK Police}

Several different factors apart from national identity and language issues may have influenced students' trust in the police. Some of the questionnaire items allowed self-assessments of those factors. Majorities of the students stated that they clearly felt influenced by the news, experiences of family and friends and observations of police action, with news being mentioned most frequently (Table 3 ).

\footnotetext{
${ }^{4}$ Four students did not indicate their country of origin.

${ }^{5}$ A multivariate linear regression shows that preference to speak Welsh in these situations was mainly driven by proficiency of speaking the language. This factor explained $62.1 \%$ of the variance $(p<.001, n=209)$. Including Welsh language predominance in the neighbourhood into the analysis only adds $3.5 \%$ and adding time living in the UK a further $2.9 \%$.

${ }^{6}$ In a multivariate regression, $30.7 \%$ of the variation was explained by 'overall preference for speaking Welsh' alone and adding naming 'Wales' as country of origin resulted in $35.1 \%$ explained variance $(n=210, p<.001)$. Specifically, both factors combined explain $31.2 \%$ of the support to make Welsh a requirement for every job at the police, again with overall preference for Welsh accounting for most (27.6\% alone).
} 
Table 3 Self-assessed influences on evaluation of police, percentages

\begin{tabular}{llllrr}
\hline & $1=$ Very & 2 & 3 & 4 & $5=$ Not at all \\
\hline News & 33.6 & 38.2 & 18.4 & 7.1 & 2.1 \\
Experience of family and friends & 29.7 & 28.6 & 20.8 & 7.4 & 12.4 \\
Observed police action & 22.3 & 33.6 & 23.3 & 9.2 & 11.3 \\
Police among family and friends & 18.7 & 28.3 & 17.7 & 9.5 & 25.1 \\
Having been a crime victim & 16.6 & 17.7 & 12.0 & 9.2 & 43.1 \\
Stopped by police & 14.8 & 21.2 & 17.0 & 9.2 & 37.5 \\
Interviewed as witness & 14.1 & 16.3 & 14.8 & 8.5 & 44.2 \\
Films, TV shows, novels & 13.8 & 24.4 & 23.3 & 14.1 & 23.7 \\
Reported to police & 13.8 & 17.3 & 18.7 & 4.6 & 44.2 \\
Fined & 11.0 & 14.1 & 11.3 & 7.4 & 53.7 \\
\hline
\end{tabular}

Percentages: differences to 100 are missing answers

On the other hand, majorities stated no influence from having been fined by police, being a witness or a crime victim. They may just not have been in such situations. Having been stopped by the police was a strong factor only for a minority. As an influential source, films, TV shows and novels tended to be much less mentioned than news. An influence by family and friends in the police was indicated by $47 \%$. One TV series deserves mentioning. The reality TV show 'Traffic Cops' has been consumed by at least half of the respondents. Welshspeakers tended to watch 'Traffic Cops" more than others (Spearman's rho $=.25, p<.001, n=$ 279).

Most of the students (Table 4) stated that their opinion on the police was neither positively nor negatively altered by their degree course, their lecturers, assigned readings or discussions with fellow students. Among the rest, there was a slightly stronger tendency to the positive rather than negative influence.

\section{Multivariate Analysis}

To explain student trust in the UK police, a multivariate linear regression has been conducted (Table 5). Gender and age of the respondents and the length of time being in Wales proved not significantly correlated to trust. The same applies to influences from the respondents' studies at university.

Media influenced trust on two levels: feeling influenced by film, TV and novels was marginally significantly positively related, while news about the police appeared not significant. In addition, students who watched the reality TV show 'Traffic Cops' had a significantly higher level of trust in the institution.

From the other self-assessed influences, most were not significantly correlated to trust in the UK police. In an interesting contrast, having family and friends in the police showed a

Table 4 Self-assessed influence of university studies, percentages

\begin{tabular}{llcr}
\hline & Positively & Neither & Negatively \\
\hline Degree course & 17.0 & 64.0 & 9.2 \\
Lecturers & 12.4 & 70.0 & 8.1 \\
Assigned readings & 12.7 & 69.3 & 8.8 \\
Student discussion & 12.7 & 67.8 & 11.0 \\
\hline
\end{tabular}

Percentages: differences to 100 are missing answers and 'do not know' 
Table 5 Multivariate analysis for trust in the police

\begin{tabular}{|c|c|c|}
\hline & Beta & Significance \\
\hline Age & .13 & .207 \\
\hline Gender & -.07 & .378 \\
\hline Years living in the UK & -.01 & .963 \\
\hline Course changed trust & .12 & .292 \\
\hline Lecturers changed trust & .11 & .316 \\
\hline Readings changed trust & -.10 & .257 \\
\hline Students changed trust & .01 & .909 \\
\hline Watching 'Traffic Cops' & .18 & .040 \\
\hline \multicolumn{3}{|l|}{ Feeling influenced by... } \\
\hline - Film. TV, novels on police & .17 & .055 \\
\hline - News about the police & .12 & .200 \\
\hline - Experiences of family and friends with police & -.25 & .027 \\
\hline - Family. friends in police & .15 & .101 \\
\hline - Observed police action & .09 & .326 \\
\hline - Interviewed as witness by police & -.06 & .563 \\
\hline - Stopped by police & .02 & .863 \\
\hline - Fined by police & -.23 & .038 \\
\hline - Reported for police & -.01 & .979 \\
\hline - Victim of crime & .18 & .125 \\
\hline Nationality indicated as 'Wales' & -.12 & .309 \\
\hline Nationality indicated as 'England' & -.09 & .273 \\
\hline Welsh speaker & -.10 & .534 \\
\hline Welsh-speaking neighbourhood & .08 & .454 \\
\hline Overall preference for using Welsh language & -.33 & .018 \\
\hline Perception overall enough Welsh spoken & .16 & .067 \\
\hline Support for Welsh language policies & .17 & .090 \\
\hline Chinese student & -.30 & .035 \\
\hline
\end{tabular}

Dependant variable is the police trust index. Significant factors at $p<.05$ bold, marginally significant factors in italics. Adjusted $R$-square $=.283, n=144, p<.001$

marginally significant relation to trusting the UK police, but those who felt informed by experiences of family and friends generally with the police had significantly less trust. Significantly less trust was also held by respondents who considered being fined by the police an influence on their attitude.

Being able to speak Welsh as such or living in a Welsh neighbourhood were not among the significant factors. Those who shared the opinion that overall, enough Welsh is spoken in certain everyday situations trusted the UK police more, a factor that was but marginally significant. Similarly marginally significant and positively correlated proved favouring measures to support the Welsh language. But crucially, respondents preferring to speak Welsh in a variety of situations measured had significantly less trust in the UK police.

Just stating Wales or England as country of origin was found unrelated to trust in the UK police. Chinese students, however, significantly tended to trust the institution.

\section{Discussion}

Apart from Scotland and Northern Ireland, Wales forms another, though lesser discussed, nonEnglish part of the UK with its own history, politics and culture. North-west Wales is seen as a 'heartland' of the Welsh language and Welsh nationalism. Welsh identities are often defined around the language, and there are consequences for trust in state institutions. A study of students at Bangor 
University in north Wales allowed a closer look at trust in the UK police. When we analysed the overall trust in the UK police, the preference to speak Welsh in various situations proved to be significant. Moreover, this influence was negative. The result illustrates the group position theory, formulated initially for race relations in the United States (Blumer 1958; Weitzer and Tuch 2005), in its application to national minorities (Bradford and Jackson 2018; Sahin and Akboga 2018). The group finding itself disadvantaged, or dominated, perceives authorities more negatively.

The UK police still must find ways to improve its standing with some of the core Welshspeaking population. The study also showed a significant relation between Welsh language preference and support for measures in favour of the language - and by implication, its speakers. Indeed, sympathy for such measures was marginally positively related to trust. Noticing that too few Welsh was spoken in everyday situations was marginally negatively related to trust in UK police, which underlines the point. These results suggest on a general level that the more policies benefit the north Wales region and its Welsh-speaking population, the more institutions gain in support. Yet, some of those measures for the language and its speakers might exclude other inhabitants of north Wales or appear this way.

Apart from preference to speak Welsh, other factors have been identified that influence trust in the UK police. Previous studies discussed relations of other minorities in the UK with the police, for example British Muslims or Polish migrants. In our sample, a large group of Chinese students were included, allowing for another observation at the side. Their case is different due to the clearly transient nature of their stay in the UK. In our study, they had particular high levels of trust in the UK police, something that may be culturally based, if one follows Hofstede's (1997, p. 32) argument. Indeed, automatically assuming that minorities have a problematic relation with the police will be misleading (Bradford and Jackson 2018).

Stating one's nationality as 'Welsh' and living in a Welsh-speaking neighbourhood did not result in different ratings of trust in police. It is a particular Welsh nationalism that influences trust in the UK police negatively, one that is shared by a language-aware subsection of the local population, desiring to make extensive use of their language.

We can be the more confident of said finding as we have taken account of several other factors that may impact on trust in a police force. The analysis shows some aspects of police work, or representations of police work that can bring about an improvement of relations to the public. We did not find that students' trust may be influenced by their studies at university. Our survey covered final year undergraduates. But, a considerable amount of media impact was found. Students, feeling influenced by films, TV shows and novels (but not by news, maybe because of the more 'mixed bag' of the reporting) had somewhat more trust in the UK police. A further clue is provided by the reality TV series 'Traffic Cops' being positively related to overall trust in police. The media consumed by students portray police as heroic characters, even in mundane settings. Thus, general media representations of the police can raise levels of trust.

Still, other factors exerted an influence. When the respondents had been fined by police, a negative effect on trust resulted. This type of encounter is known to be problematic and likely to upset those punished. Family and friends must have told the respondents about particularly negative experiences, so that the influence on trust was clearly negative. In contrast, having family and friends in the police had a marginally positive effect on perceived fairness of police officers. Both reaffirm results of an earlier study with law students (Machura et al. 2014, p. 297). A limitation of the present study, when it comes to a generalisation, is that university students' views may differ from the general population, or even young people who are not at university. On the other hand, Welsh-speaking students are predominantly from local families in rural communities steeped in traditional culture, which on top of it, is being reinforced by 
separate education in Welsh-medium schools. In such an environment, student views may well mirror a common attitude. It is possible that results are more positive when Welsh-speakers in the north are asked specifically about the local police force with its embrace of Welsh language and culture. A later study with a convenience sample of inhabitants and not only students thus concentrated on opinion specifically about North Wales Police. Now, preference to speak Welsh correlated positively with support for the local police (Machura et al. 2019, p. 69). In another result, indicating an influence of nationalist feelings, a range of UK institutions was trusted more highly by respondents who spoke no Welsh and those who indicated positive feelings for the British symbol of the "Union Jack" (Machura et al. 2019, p. 70). Such results again highlight the importance of the language issue in relation to institutions in societies divided along such lines.

Some conclusions can be drawn that are likely to apply to a variety of social and political situations. The results of this study point to the importance of minority language politics, of media portrayals, and of experience, either personal or by people close to the individual, for trust in police, a key state institution. It becomes clear that the state agencies such as the police cannot take public trust for granted and need to work on their appearance, especially in areas where sizable minorities exist.

The present study has included procedural justice as component of trust in the police. Citizenpolice relations improve if police are seen to respect individual's rights, act politely and without bias, provide the opportunity to voice one's views, and adhere to social values and legal norms. The more people perceive police to perform their duties in this way, the higher levels of trust are (Tyler et al. 2015; Dalton et al. 2009; Bradford 2014; Oliveira and Murphy 2015; Machura et al. 2014, 2019). The regard in which minority language speakers and locals generally hold the police may thus rise and fall with the quality of police work not only how effective police deal with crime and respond to concerns but also by the perceived fairness of police officers.

Some citizens in north-west Wales show a strong preference of speaking Welsh, including the encounters with authorities. Similar constellations can be found elsewhere for selfconscious minority groups demanding equal or preferential status for their language. In our study, Bangor students inclined to communicate in Welsh had more distrust in the UK police. The intricacy involved in this becomes already clear when only concentrating on police recruitment policy. One respondent noted in an open comment field on the questionnaire:

When for example a police officer speaks Welsh to me, I feel more comfortable as it is my mother tongue, I feel they should prioritise the Welsh language within establishments especially with the Welsh heartlands.

However, this could dismay those unable to speak Welsh, as the following two voices illustrate: 'Welsh is important, but it is unfair not to allow non-Welsh speakers certain jobs.' 'It is hard enough to find employment without the ability to speak Welsh fluently.' What for some is a self-evident language right, for others appears as a threat to their economic future.

Open Access This article is licensed under a Creative Commons Attribution 4.0 International License, which permits use, sharing, adaptation, distribution and reproduction in any medium or format, as long as you give appropriate credit to the original author(s) and the source, provide a link to the Creative Commons licence, and indicate if changes were made. The images or other third party material in this article are included in the article's Creative Commons licence, unless indicated otherwise in a credit line to the material. If material is not included in the article's Creative Commons licence and your intended use is not permitted by statutory regulation or exceeds the permitted use, you will need to obtain permission directly from the copyright holder. To view a copy of this licence, visit http://creativecommons.org/licenses/by/4.0/. 


\section{References}

Asimow, M., Greenfield, S., Jorge, G., Machura, S., Osborn, G., Robson, P., Sharp, C., \& Sockloskie, R. (2005). Perceptions of lawyers - a transnational study of student views on the image of law and lawyers. International Journal of the Legal Profession, 12(3), 407-436.

Barbalet, J. (2009). A characterization of trust, and its consequences. Theory and Society, 38(4), 367-382.

BBC (n.d.). Wales election 2016. Results. London: BBC. Retrieved from www.bbc.co.uk/news/election/2016 /wales/results.

BBC news (2019). European Election 2019: Brexit party tops poll in Wales. London: BBC. Retrieved from https://www.bbc.co.uk/news/uk-wales-politics-48417474.

Blumer, H. (1958). Race prejudice as a sense of group position. The Pacific Sociological Review, 1(1), 3-7.

Bowling, B., Reiner, R., \& Sheptycki, J. (2019). The politics of the police (5th ed.). Oxford: Oxford University Press.

Bradford, B. (2014). Policing and social identity: procedural justice, inclusion and cooperation between police and public. Policing and Society, 24(1), 22-43.

Bradford, B., \& Jackson, J. (2018). Police legitimacy among immigrants in Europe: Institutional frames and group position. European Journal of Criminology, 15(5), 567-588.

Bradford, B., Jackson, J., \& Hough, M., (2013). Police futures and legitimacy: redefining 'good policing'. Retrieved from http://www.academia.edu/2110461/Police_Futures_and_Legitimacy_Redefining_Good_ Policing.

Bradford, B., Topping, J., Martin, R., \& Jackson, J. (2018). Can diversity promote trust? Neighbourhood context and trust in the police in Northern Ireland. Policing and Society. https://oi.org/10.1080/10439463.2018.

Carter, H. (2004). Police take fresh look at Sons of Glyndwr. The Guardian 11 March 2004. Retrieved from https:/www.theguardian.com/uk/2004/mar/11/helencarter.

Czapska, J., Radomska, E., \& Wójcik, D. (2014). Police legitimacy, procedural justice, and cooperation with the police: A polish perspective. Varstvoslovje, 16(4), 453-470.

Dalgleish, D., \& Myhill, A. (2004). Reassuring the public: A review of international policing interventions. London: Home Office, Home Office Findings.

Dalton, I., Jones, V. M. L., Machura, S., Ngaihte, H., Norton, T. P., \& Pritchard, M. (2009). Speeding, the chief constable and trust in North Wales Police. Papers from the British Criminology Conference, 9, 92-110. Retrieved from https://www.britsoccrim.org/volume9/6.Dalton09.pdf.

Day, G. (2002). Making sense of Wales: a sociological perspective. Cardiff: University of Wales Press.

Day, G. (2015). Sociology in and of Wales: an overview. Irish Journal of Sociology, 23(1), 62-82.

Day, G., Davis, H., \& Drakakis-Smith, A. (2006). Being English in North Wales: Inmigration and the inmigrant experience. Nationalism and Ethnic Politics, 12(3-4), 577-598.

Day, G., Davis, H., \& Drakakis-Smith, A. (2010). 'There's one shop you don't go into if you are English': The social and political integration of English migrants into Wales. Journal of Ethnic and Migration Studies, 36(9), 1405-1423.

Dirikx, A., \& Van den Bulck, J. (2014). Media use and the process-based model for police cooperation: an integrative approach towards explaining adolescents' intentions to cooperate with the police. British Journal of Criminology, 45(2), 344-365.

Dirikx, A., Gelders, D., \& Van den Bulck, J. (2013). Adolescent perceptions of the performance and fairness of the police: Examining the impact of television exposure. Mass Communication and Society, 16(1), $209-332$.

Easton, D. (1965). A systems analysis of political life. New York: Wiley.

Ellison, G., Pino, N., \& Shirlow, P. (2013). Assessing the determinants of public confidence in the police: a case study of a post-conflict community in Northern Ireland. Criminology and Criminal Justice, 13(5), 552-576.

Emmet, I. (1964). A north Wales village: a social anthropological study. London: Routledge and Kegan Paul.

Griffith, C. E. (2017). The disjuncture between confidence and cooperation: Police contact amongst Polish migrants and established residents. European Journal of Criminology, 15(2), 197-216.

Hamilton, P. (2004). Converging nationalisms: Québec, Scotland, and North Wales in comparative perspective. Nationalism and Ethnic Politics, 10(4), 657-685.

Hardin, R. (1992). The street-level epistemiology of trust. Analyse und Kritik, 14(2), 152-176.

Harris, B. (2014). Wales must confront uncomfortable truths about racism. Manchester Policy Blogs: Ethnicity 26 June 2014. Retrieved from blog.policy.manchester.ac.uk/featured/2014/06/wales-must-confrontuncomfortable-truths-about-racism/.

Heenan, N., Wilkinson, K., Griffiths, D., Searles, B., Seloom, M., Woolford, R., Williams, C., \& Machura, S. (2008). Trust in police community support officers. The views of Bangor students. Papers from the British Criminology Conference, 8, 134-152. Retrieved from http://www.britsoccrim.org/volume8/BCCvol82008. pdf.

Hesse, H.-A. (1998). Experte, Laie, Dilettant. Opladen: Westdeutscher Verlag. 
Hofstede, G. (1993). Interkulturelle Zusammenarbeit. Wiesbaden: Gabler. Retrieved from. https://doi. org/10.1007/978-3-322-90037-1.

Hofstede, G. (1997). Lokales Denken, globales Handeln. Munich: Deutscher Taschenbuch Verlag.

Huq, A. Z., Tyler, T. R., \& Schulhofer, S. J. (2011). Mechanisms for eliciting cooperation in counterterrorism policing: evidence from the United Kingdom. Journal of Empirical Legal Studies, 8(4), 728-761.

Jackson, J., \& Sunshine, J. (2007). Public confidence in policing: a neo-Durkheimian perspective. British Journal of Criminology, 47(2), 214-233.

Jackson, J., Hough, M., Bradford, B., Pooler, T. M., Hohl, K., \& Kuha, J. (2011). Trust in justice: Topline results from round 5 of the European social survey. London: European Social Survey, ESS Topline Results Series, no. 1. Retrieved from: http://www.europeansocialsurvey.org/docs/findings/ESS5_toplines_issue_1 trust_ in_justice.pdf].

Jones, J., \& Holmes, T. (2013). An exploratory study of the crime threat to small and medium sized farm based enterprises on Ynys Mon. Aberystwyth: Aberystwyth University.

Jones, H., \& Holzinger, O. (2016). 2016 assembly election results. Cardiff: Research Service National Assembly for Wales. Retrieved from http://www.assembly.wales/research\%20documents/16-30-2016\%20 assembly\%20election\%20results/16-030-web-english.pdf.

Leventhal, G. S. (1980). What should be done with equity theory? In K. J. Gergen, M. S. Greenberg, \& R. H. Willis (Eds.), Social exchange: advances in theory and research, vol. 9 (pp. 27-55). New York: Plenum.

Lind, E. A. (2019). The study of justice in social psychology and related fields. Manuscript.

Loader, I., \& Mulcahy, A. (2006). Policing and the condition of England. Reprint. Oxford: Oxford University Press.

Luban, D. J. (1988). Milgram revisited. Researching Law, 9(2) 1, 4-11.

Luhmann, N. (1975). Legitimation durch Verfahren (2nd ed.). Darmstadt: Luchterhand.

Machura, S. (2001). Fairneß und Legitimität. Baden-Baden: Nomos.

Machura, S. (2006). Fernsehgerichtshows: Spektakel des Rechts. Paragrana, 15(1), 174-188.

Machura, S., \& Kammertöns, A. (2009). Recht im Schulunterricht, Medieneinflüsse und die Attraktivität von Rechtsberufen. Zeitschrift für Rechtssoziologie, 30(2), 235-259.

Machura, S. (2011). Media influence on the perception of the legal system. In K. Papendorf, S. Machura, \& K. Andenæs (Eds.), Understanding law in society (pp. 239-283). Zurich: Lit Verlag.

Machura, S., Correia Ramos, N. M., Rooney, T., \& Warmald, S. (2013). How studying law, media and experience influence trust in the courts and the police. A comparison of law and language students at Bangor University. In J. Estermann (Ed.), Der Kampf ums Recht. Akteure und Interessen im Blick der interdisziplinären Rechtsforschung (pp. 150-167). Vienna: Lit Verlag.

Machura, S., Love, T., \& Dwight, A. (2014). Law students' trust in the courts and the police. International Journal of Law, Crime and Justice, 42(4), 287-305.

Machura, S., Jones, S. O. P., Würgler, A., Cuthbertson, J., \& Hemmings, A. (2019). National identity and distrust in the police: The case of North West Wales. European Journal of Criminology, 16(1), 60-80.

Mann, R. (2004). Two civil societies? An investigation into the boundaries surrounding the bilingual organisation of civil society in Wales. Unpublished PhD Dissertation, Bangor University, United Kingdom.

Mann, R., \& Fenton, S. (2017). Nation, class and resentment. The politics of national identity in England. Scotland and Wales: Palgrave McMillan.

Mann, R., \& Plows, A. (2016). East, west and the bit in the middle. Localities in North Wales. In M. Jones, S. Orford, \& V. Macfarlane (Eds.), People, places and policy. Knowing contemporary Wales through new localities (pp. 95-117). Abington: Routledge.

Murphy, K., Sargeant, E., \& Cherney, A. (2015). The importance of procedural justice and police performance in shaping intentions to cooperate with the police: Does social identity matter? Europan Journal of Criminology, 12(6), 719-738.

Myhill, A., \& Beak, K. (2008). Public confidence in the police. London: National Policing Improvement Agency. Retrieved from http://library.college.police.uk/docs/npia/public-confidence-in-the-police.pdf.

Oliveira, A., \& Murphy, K. (2015). Race, social identity, and perception of police bias. Race and Justice, 5I(3), $259-277$.

Osmond, J. (2009). The lie of the land. Cardiff: Arts Council of Wales. Retrieved from http://www.arts. wales/Âfunding/john-osmond-the-lie-of-ghe-land.

Quinton, P., \& Tuffin, R. (2007). Neighbourhood change: the impact of the national reassurance policing programme. Policing, 1(2), 149-160.

Reiner, R. (1992). Policing a postmodern society. The Modern Law Review, 55(6), 761-781.

Reiner, R., \& O'Connor, D. (2015). Politics and policing: the terrible twins. Retrieved from https://s3. amazonaws.com/academia.edu.documents/38370066/03-Fleming-Chap03-v1.pdf?

Roberts, D. (2009). Bangor University, 1884-2009. Cardiff: University of Wales Press. 
Sahin, O., \& Akboga, S. (2018). Ethnic identity and perceptions of the police in Turkey: The case of Kurds and Turks. Policing and Society, 29, 985-1000. https://doi.org/10.1080/10439463.2018.1477777.

Smith, M. (2019). Compared to Scots, Welsh people are more likely to believe your parentage makes you Welsh, but less likely to think that living in Wales does. Retrieved from https://yougov.co.uk/topics/politics/articlesreports/2016/09/29/what-makes-person-welsh-according-welsh-people.

Stats Wales (2019). Annual population survey estimates of persons aged 3 and over who say they can speak Welsh by local authority and measure. Retrieved from https://statswales.gov.wales/Catalogue/WelshLanguage/AnnualPopulationSurveyEstimatesOfPersonsAged3andOverWhoSayTheyCanSpeakWelsh-byLocalAuthority-Measure.

Sunshine, J., \& Tyler, T. R. (2003). The role of procedural justice and legitimacy in shaping public support for policing. Law and Society Review, 37(3), 513-547.

Sztompka, P. (1998). Trust, distrust and two paradoxes of democracy. European Journal of Social Theory, 1(1), 19-32.

Topping, J., \& Byrne, J. (2016). Shadow policing: the boundaries of community-based 'policing' in Northern Ireland. Policing and Society, 26(5), 522-543.

Tyler, T. R. (2000). Multiculturalism and the willingness of citizens to defer to law and to legal authorities. Law \& Social Inquiry, 25(4), 983-1019.

Tyler, T. R. (2006). Why people obey the law (2nd ed.). Princeton: Princeton University Press.

Tyler, T. R., \& Huo, Y. J. (2002). Trust in the law. New York: Russell Sage Foundation.

Tyler, T. R., \& Jackson, J. (2013). Future challenges in the study of legitimacy and criminal justice. New Haven, CT: Yale Law School. Retrieved from: http://ssrn.com/abstract=2141322.

Tyler, T. R., \& Lind, E. A. (1992). A relational model of authority in groups. In M. Zanna (Ed.), Advances in experimental social psychology, vol. 25 (pp. 115-191). New York: Academic Press.

Tyler, T. R., Goff, P. A., \& MacCoun, R. J. (2015). The impact of psychological science on policing in the United States: procedural justice, legitimacy, and effective law enforcement. Psychological Science in the Public Interest, 16(3), 75-109.

Van Craen, M. (2012). Determinants of ethnic minority confidence in the police. Journal of Ethnic and Migration Studies, 38(7), 1029-1047.

Weber, M. (1968). Economy and society. New York: Bedminster Press.

Weitzer, R. (1985). Policing a divided society: obstacles to normalization in Northern Ireland. Social Problems, 33(1), 41-55.

Weitzer, R., \& Tuch, S. (2005). Racially biased policing: determinants of citizen perception. Social Forces, 83(3), 1009-1030.

Williams, M. L., \& Tregidga, J. (2014). Hate crime victimization in Wales. Psychological and physical impacts across seven hate crime victim types. British Journal of Criminology, 54(5), 946-567.

Publisher's Note Springer Nature remains neutral with regard to jurisdictional claims in published maps and institutional affiliations. 